\title{
Gyre System in Lake Biwa Derived from Recent Current Measurements
}

\author{
Shuichi ENDOH and Yasuaki OKumura
}

\begin{abstract}
On the basis of recent current measurements, we propose a new gyre system in Lake Biwa during summer. A great volume of current data was obtained with automatic current meters moored in the surface layer of Lake Biwa during 1977-1991. This data was statistically analyzed to obtain information regarding the time-averaged current velocity field. Trajectories of several drifters tracked by radar were also analyzed to explore typical surface circulation patterns. As a result, the mean surface circulation was found to consist of two large gyres, one counterclockwise and the other clockwise. The positions of these gyres differ substantially from those estimated in previous studies. The so-called Third Gyre was not clearly observed.
\end{abstract}

Key words : Lake Biwa, gyre system, surface circulation, current meter, drifter tracking

\section{Introduction}

It is well-known that gyrate currents (gyres) are present in the surface layer of Lake Biwa during the season of thermal stratification (ENDOH et al., 1981). SudA et al. (1926) first proposed the presence of three gyres, namely, the First (counterclockwise), Second (clockwise) and Third (counterclockwise). Subsequent citations of this gyre system (Fig. 1) have since gained acceptance largely because of a paucity of direct current measurements of gyres.

Окамото and Morikawa (1961a) found that the gyre in Lake Biwa is in geostrophic balance and can be estimated from water temperature distribution. On the basis of that study, a number of observations have been carried out to obtain horizontal and vertical distributions of water temperature (density) so as to evaluate the current velocity field by dynamic calculation or a diagnostic analysis (Окамото and Morikáwa, 1961b; KUNISHI et al., 1967; ENDOH, 1978; IM. AWAKI et al., 1979 ; ЕNDOH et al., 1981). Figure 2 shows an example of water temperature distri-

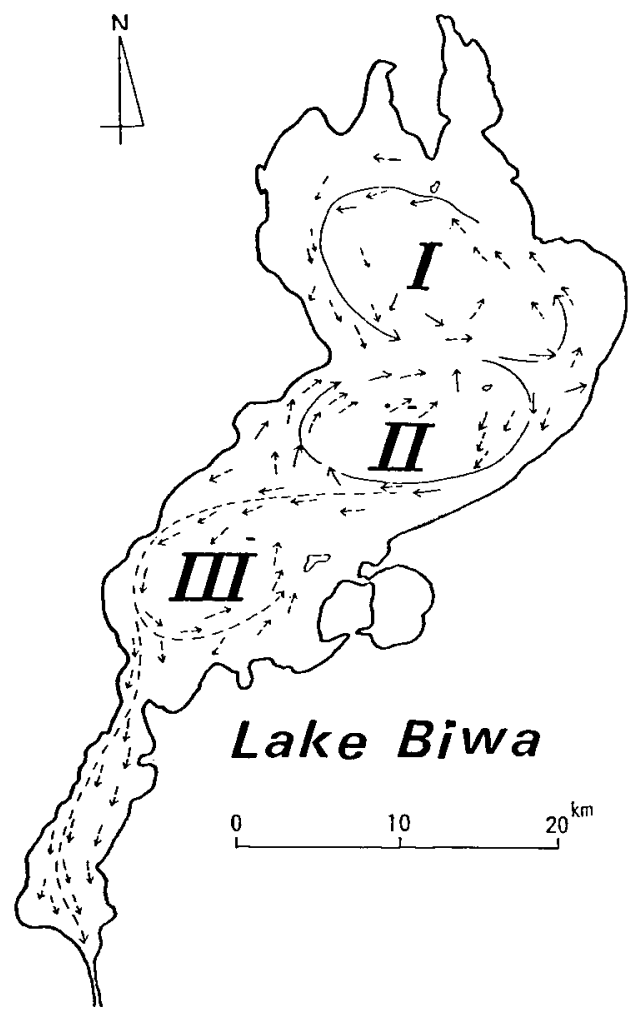

Fig. 1. Gyre system in Lake Biwa proposed by SUDA et al. (1926). 


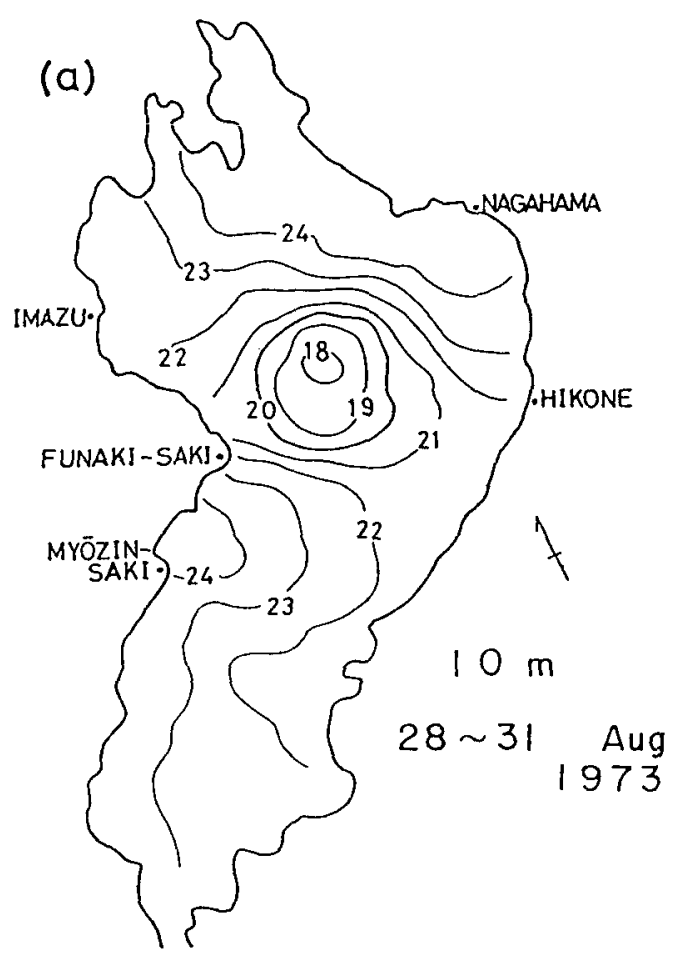

(b)

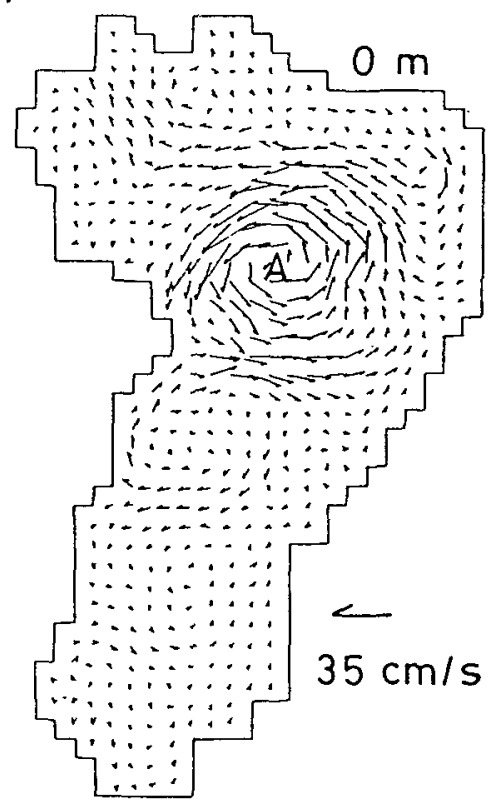

Fig. 2. (a) Horizontal distribution of water temperature at $10 \mathrm{~m}$ averaged over four days, 28-31 August 1973. (b) Distribution of horizontal velocity calculated by diagnostic model (after ENDOH, 1978). bution in summer and the diagnostically evaluated surface velocity field (ENDOH, 1978). The colder water region in this figure corresponds to a cyclonic gyre with an estimated current velocity of $10-30 \mathrm{~cm} \cdot \mathrm{sec}^{-1}$. According to the results of many water temperature analyses including those in Figure 2, the position of a large cyclonic gyre (the First Gyre) differs greatly from that of Suda et al. (1926). Strictly speaking, these studies were not based on direct measurement but were inferred from the density field. Therefore it was necessary to verify the above estimate by performing direct current measurements of gyres.

In this paper, by integrating the results of recent current measurements, we propose a new position and characteristics for gyres in Lake Biwa.

\section{Observations}

Recently, with the development of various new techniques for measuring water current velocity, a great deal of information on water movements in Lake Biwa have been accumulated. We applied two techniques; continuous current recording by automatic current meters ; and tracking of drifters by radar.

Since 1977, we have carried out a great number of continuous current measurements in Lake Biwa using automatic current meters (ENDoh et al., 1982 ; ОкuмuRa and ENDOH, 1985 ; ENDOH and OKumuRA, 1989). The current meters used are Aanderaa RCM-4, ALEC ACM4, and Okumura's DCM-3 (Okumura, 1992). The properties of these current meters and the method of field observation have been described in detail by OKumura and Endoh (1985). Accuracy of current speed measurement is within $\pm 1 \mathrm{~cm}$. $\mathrm{sec}^{-1}$ for all the current meters. Current direction is accurate to \pm 5 degrees for $\mathrm{RCM}-4$ and DCM -3 , and \pm 2 degrees for ACM4.

Figure 3 shows the locations of current meter moorings in August or September of 1977-1991. These current measurements were performed at depths of $5 \sim 7$ which corresponds to the epilimnion since the thermocline developed at $13 \sim 18 \mathrm{~m}$ that season in Lake Biwa. These measurements were continued annually for a 


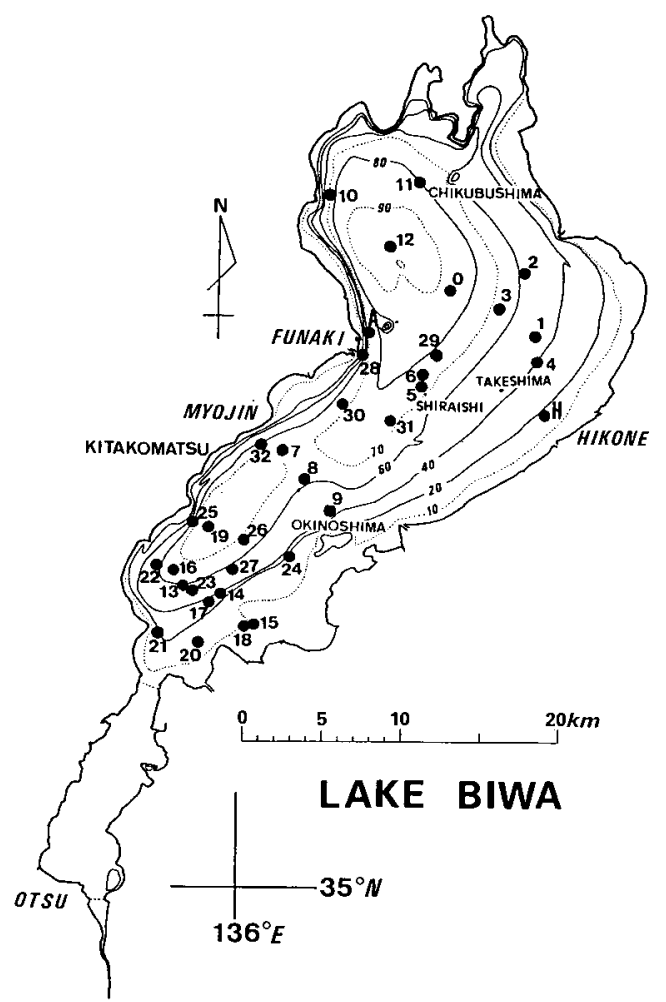

Fig. 3. Bathymetric map of Lake Biwa showing locations of current meter moorings in the surface layer during summers, 1977 to 1991. Some depth contours shown in meters.

period of about one month, during which data regarding current velocity, current direction, and water temperature were obtained every ten minutes. The duration of current measurements at each mooring site is shown in Table 1.
In addition to this Eulerian method, we developed a new method of Lagrangean current measurement, that is, tracking of drifters by radar (ENDOH et al., 1987). This method enables us to determine simultaneously the positions of drifters with an accuracy of about $50 \mathrm{~m}$ even at night and under bad weather conditions. The radar scanner was set on an elevated location near the lake shore or on the island. A drifter is constructed from a window shade drogue in the water connected by a rope to a surface float, and a radar wave reflector on top of a pole above the water surface. The procedure and analysis of this method are described in detail by ENDOH et al. (1987).

Radar trackings of drifters have been carried out almost every year since 1981. In this paper, we show two results obtained in 1983 and 1986. The former observation was carried out on 1-4 September 1983 by setting a radar scanner on Takeshima islet. The latter was done on 13-15 September 1986 at Kitakomatsu, on the western shore (Fig. 3). In both cases, several drifters were traced at 30 -min intervals by taking photographs of a radar display. The reading of the drifter position is estimated to be accurate within $1 \%$, that is, about $50 \mathrm{~m}$.

\section{Results and discussion}

Figure 4 shows the frequencies of current direction (current roses) based on current data obtained every ten minutes. Each of the 16 current directions is expressed by a radial line

Table 1. Current meter moorings in surface layer of Lake Biwa during summer, 1977 to 1991.

\begin{tabular}{ccc}
\hline $\begin{array}{c}\text { Period of current } \\
\text { measurement }\end{array}$ & $\begin{array}{c}\text { Measurement } \\
\text { depth }(\mathrm{m})\end{array}$ & $\begin{array}{l}\text { Station code } \\
\text { (Current meter*) }\end{array}$ \\
\hline 1 Aug.-31 Aug., 1977 & 3 & A(R), H(R) \\
1 Aug.- 8 Sep., 1981 & 5 & $0(\mathrm{D}), 1(\mathrm{R}), 2(\mathrm{R}), 3(\mathrm{R})$ \\
9 Aug.-14 Sep., 1982 & 5 & $4(\mathrm{R}), 5(\mathrm{R})$ \\
8 Aug.- 4 Sep., 1983 & 5 & $6(\mathrm{R})$ \\
11 Aug.-15 Sep., 1986 & 5 & $7(\mathrm{R}), 8(\mathrm{R}), 9(\mathrm{R})$ \\
10 Aug.-11 Sep., 1987 & 5 & $10(\mathrm{R}), 11(\mathrm{R}), 12(\mathrm{R})$ \\
8 Aug.- 2 Sep., 1988 & 7 & $13(\mathrm{R}), 14(\mathrm{R}), 15(\mathrm{R})$ \\
6 Sep. -26 Sep., 1989 & 7 & $16(\mathrm{R}), 17(\mathrm{R}), 18(\mathrm{R}), 19(\mathrm{~A}), 20(\mathrm{~A}), 21(\mathrm{D})$ \\
8 Aug.-31 Aug., 1990 & 7 & $22(\mathrm{D}), 23(\mathrm{~A}), 24(\mathrm{R}), 25(\mathrm{R}), 26(\mathrm{R}), 27(\mathrm{~A})$ \\
1 Aug.-31. Aug., 1991 & 7 & $28(\mathrm{R}), 29(\mathrm{~A}), 30(\mathrm{R}), 31(\mathrm{~A}), 32(\mathrm{R})$ \\
\hline
\end{tabular}

* current meter $\mathrm{R}: \mathrm{RCM}-4, \mathrm{D}: \mathrm{DCM} 3, \mathrm{~A}: \mathrm{ACM} 4$ (See text) 


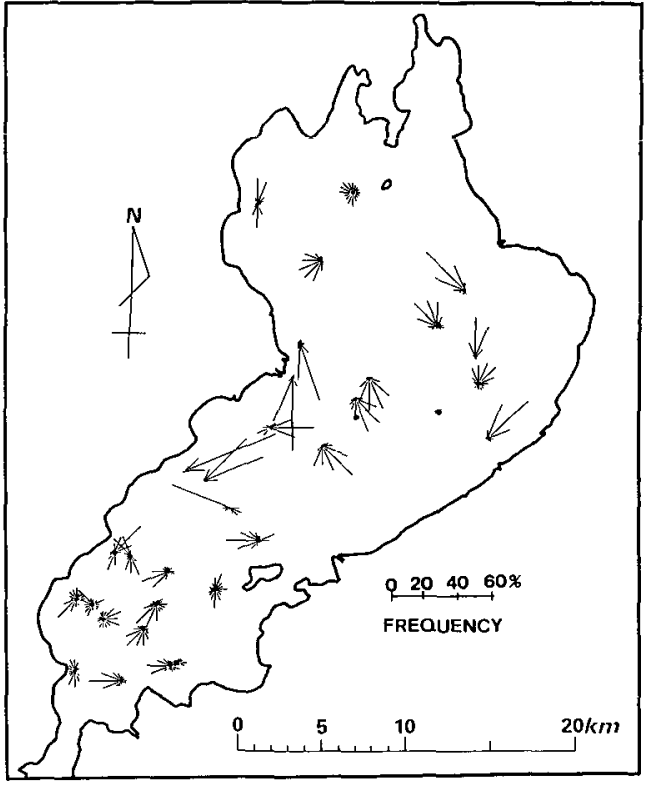

Fig. 4. Frequency percent of current directions represented by 16 radial lines.

extending from the center position. The length of each line represents the frequency (\%) of a given current direction. The current pattern in the northern half of the basin (between Sta. 12 and Sta. 31 in Fig. 3) evidently indicates that the surface-layer water is circulating in a counterclockwise direction. This is the First gyre as discussed below. The current off Myojin (Stas. 7 and 32) is dominant in a northeast direction. In contrast, no dominant current direction can be clearly detected near the southern end of the basin.

Figure 5 shows a horizontal distribution of current vectors averaged over about one month. Although this figure does not indicate the simultaneous distribution of the current, it shows the typical surface circulation pattern during summer. For example, the averaged current vectors at the two adjacent stations 7 and 32 are almost the same, even though the data were obtained independently in 1986 and 1991. A large counterclockwise gyre is visually evident with a typical current speed of $10 \mathrm{~cm} \cdot \mathrm{sec}^{-1}$ in the northern portion of the basin. To the south of this gyre, a clockwise gyre can be seen. The current near the southern end of the basin is

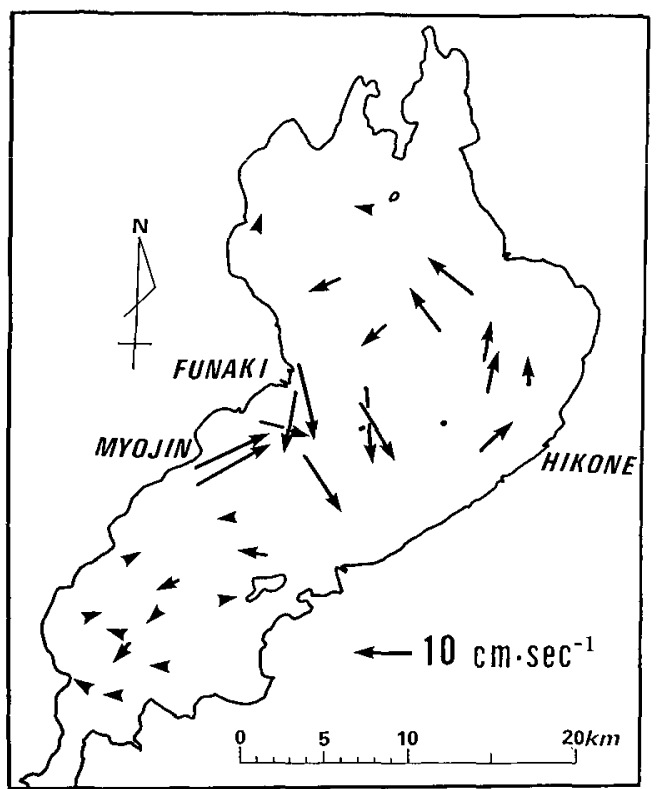

Fig. 5. Horizontal distribution of current vectors during summers of 1977-1991, averaged over about one month.

very weak, and no gyrate currents can be detected there.

Figure 6 shows the trajectories of surface layer drifters tracked by radar in 1983 and 1986 as mentioned above (after ЕNDOH et al., 1987). In this figure, trajectories of four drifters are shown for each observation with marks (circles or triangles) every 6 hours. Numerals beside the marks indicate day and hour (for example, 312 means $12: 00$, 3rd September). In the 1983 tracking (symbol A in Fig. 6), all four drifters are at a depth of $10 \mathrm{~m}$ and moving in a counterclockwise direction at an average speed of 10 $\mathrm{cm} \cdot \mathrm{sec}^{-1}$, and rotating once every 2 or 3 days. In the 1986 tracking (symbol B), the four drifters at a depth of $5 \mathrm{~m}$ rotate clockwise with a speed of about $10 \mathrm{~cm} \cdot \mathrm{sec}^{-1}$. These current patterns and speeds are almost equal to those obtained by current meter records shows in Figure 5.

There are many kinds of currents in Lake Biwa (e.g., Окамото, 1984). ENDOH and OKumura (1989) pointed out that gyres, wind-driven currents, internal waves and inertial oscillation are dominant in the surface layer of Lake Biwa during summer. By calculating a time average 


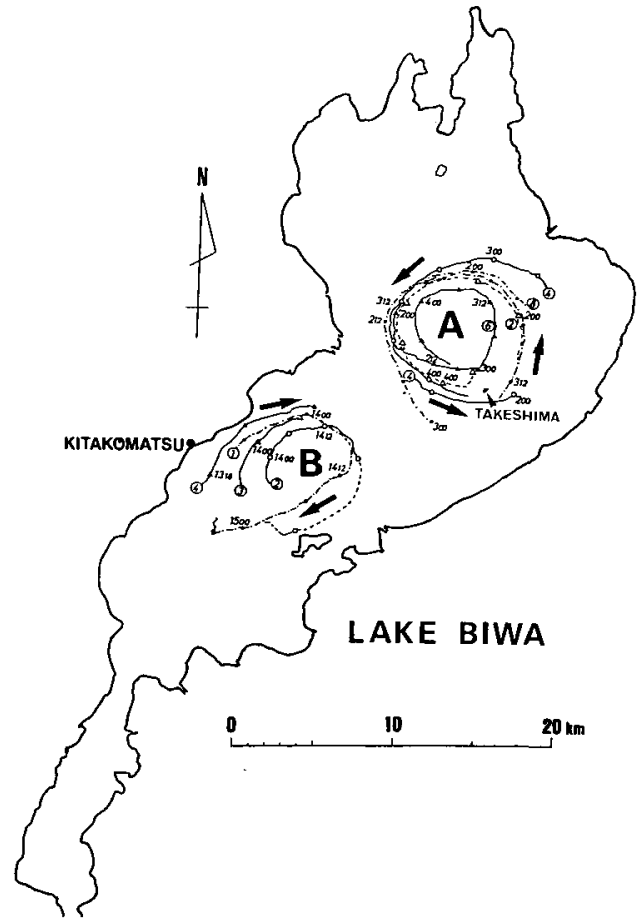

Fig. 6. Trajectories of drifters at a surface layer tracked by rader during summers of 1983 (A) and 1986 (B). Numerals show day and hour, e.g., 312 means 12: 00 on 3rd September (after ENDOH et al., 1987).

of the current data (Fig. 5), we can remove the oscillatory current associated with inertial oscillation and internal waves. The wind driven current would have been included in Figure 5, but it is not so effective on the timeaveraged current field since the wind is rather calm on Lake Biwa during the summer season. Trajectories obtained in drifter trackings involve some effects of wind-driven and oscillatory currents. In the case shown in Figure 6, however, the wind was weak ; mean wind speed was $1.5 \mathrm{~m} \cdot \mathrm{s}^{-1}$ for $1-4$ September 1983 , and 2.0 $\mathrm{m} \cdot \mathrm{s}^{-1}$ for $13-15$ September 1986 (from the Hikone Meteorological Observatory). Inertial oscillation and internal waves were also found to be weak according to the current meter records during those radar trackings. The rotating movement of surface drifters in Figure 6 is thus attributable mainly to gyres.

On the basis of observational results shown in Figures 5 and 6 as well as temperature distribu-

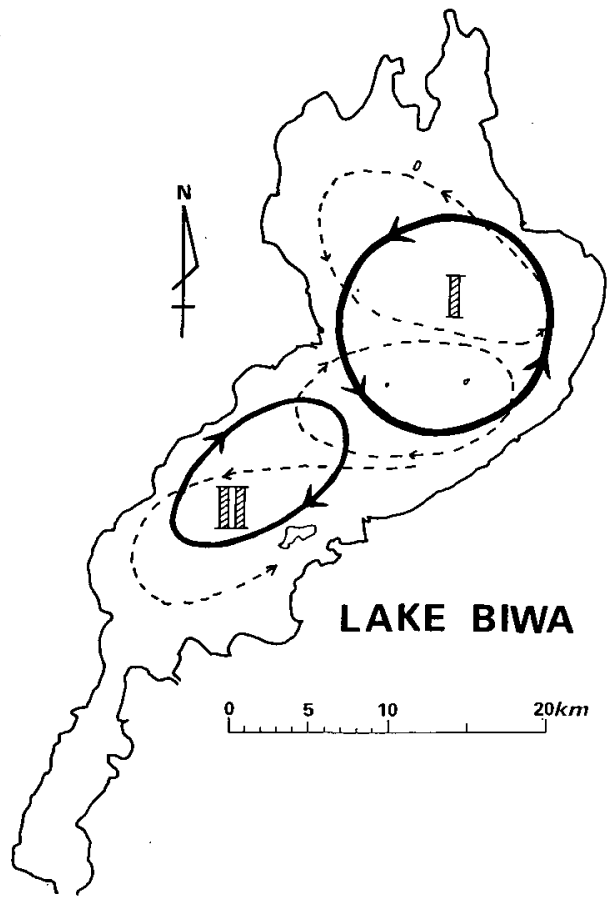

Fig. 7. Schematic pattern of gyre system in Lake Biwa. Solid line represents gyre system proposed in this study, broken line that proposed by SUDA et al. (1926).

tion such as that in Figure 2, we can conclude the existence of two large gyres, the counterclockwise First Gyre and the clockwise Second Gyre. These positions, schematically illustrated in Figure 7 (thick solid line), are considerable different from those estimated by SuDA et al. (1926) (broken line). Though the work of SuDA et al. (1926) was significant and estimable at that time, it should be noted that the accuracy of their current measurements was low. They measured the current velocity instantaneously only at several points by using current meters from a drifting boat. Therefore, the proposal of the revised gyre positions in Figure 7 is mainly due to the recent development of new techniques in current measurement and data accumulation.

The revised positioning of gyres is important in explaining distributions of dissolved or suspended materials in water as well as sedimentation processes. For example, a high con- 
centration of chlorophyll $a$ was observed near the center of the First Gyre (SaIjo and SA. КАмото, 1970). KaMiTANi (1988) found very fine bottom sediment in this area. The mechanisms of these distributions has yet to be well explained, but the horizontal convergence of surface water associated with the gyre (ENDOH, 1986) should play an important role in the transportation and selection of suspended materials. The current speed of the gyres is critical for problems arising from the transportation of materials related to water pollution. It is well -known that the electric conductivity of surface water is almost uniform in the north basin of Lake Biwa. This should be due to the intense water mixing and diffusion by stable gyres with a velocity as high as $20 \mathrm{~cm} \cdot \mathrm{sec}^{-1}$.

\section{Acknowledgements}

We wish to express our sincere thanks to Professor Emeritus I. Окамото of Shiga University, and Professors S. OKudA of Okayama University of Science and A. Yamamoto of Osaka Electro-Communication University for their useful discussions. We also thank Mr. M. KOBAYASHI and the many students of Shiga University and Osaka Electro-Communication University for their help in field observations and data analysis. This study was supported in part by the Ministry of Education, Science and Culture, Japan.

\section{摘要}

\section{最近の測流結果からみたびわ湖の環流系}

最近 15 年間に得られた自記流向流速計による 連続測流，およびレーダによるブイの追跡観測の 結果から, 夏季のびわ湖表層には, 反時計回りの 第 1 環流と, 時計回りの第 2 環流が安定して存在 していることが確認された。これらの環流の位置 は，従来考えられていた位置とは大きく異なって いる。いわゆる第 3 環流については影著には認め られなかった。

\section{References}

ENDoH, S. (1978) : Diagnostic analysis of water circulations in Lake Biwa. J. Oceanogr. Soc. Japan, 34: 250-260.
ENDOH, S. (1986): Diagnostic study on the vertical circulation and the maintenance mechanisms of the cyclonic gyre in Lake Biwa. J. Geophys. Res., $91 \mathrm{Cl}$ : 869-876.

Ennoh, S., I. Okamoto and M. Nakai (1981) : Circular currents in the north basin of Lake Biwa (I). Jpn. J. Limnol. 42 : 144-153 (in Japanese).

Endoh, S., I. OKamoto, R. Kishida and T. Kimura (1982): Continuous records of water currents in Lake Biwa (I). Water Temp. Res., 26-3 : 35-47 (in Japanese).

Endoh, S., I. Okamoto, Y. Okumura T. Tamura, K. Takano, Y. Hamai, T. Kodani, Y. Hayami, H. Asada, H. Kawamura and K. Iwane (1987): Measurements of lake current by using a radar. Mem. Fac. Educ., Shiga Univ., 37:27-38 (in Japanese).

Endoh, S. and Y. Okumura (1989): Continuous current measurements in Lake Biwa (II). Jpn. J. Limnol., 50 : 341-350 (in Japanese).

Imawaki, S., S. Endoh and H. Kunishi (1979): Study on the water circulation in Lake Biwa. Annu. Disaster Prev. Res. Inst. Kyoto Univ., $22 B 2$ : 591-599 (in Japanese).

Kamitani, T. (1988): Grain size distribution of muds and its depositional process in Lake Biwa. J. Res. Gr. Clas. Sed. Japan, 5:23-33 (in Japanese).

Kunishi, H., I. Окамото and H. Sato (1967); Observation of water circulation in Lake Biwa, Annu. Disaster Prev. Res. Inst. Kyoto Univ., 1OB : 321-329 (in Japanese).

Окамото, I. (1984): Water currents. p. 175-183. In S. Horie (ed.), Lake Biwa, Dr. Jung Publishers, Netherlands.

Okamoto, I. and M. Morikawa (1961a): Water circulation in Lake Biwa-ko as deduced from the distribution of water density. Jpn. J. Limnol. 22 : 193-200 (in Japanese).

Oкамото, I. and M. Morikawa (1961b): The determination of water circulation in Lake Biwa-ko by the method of geopotential height. Mem. Fac. Educ., Shiga Univ., 11:27-33 (in Japanese).

Okumura Y. (1992): A current meter for continuous measurements of water movements in Lake Biwa. SICE, 28-5 : 640-642 (in Japanese).

Okumura, Y. and S. ENdoh (1985) : Continuous current measurements in Lake Biwa (I). Jpn. J. Limnol., 46 : 135-142 (in Japanese).

Sajo, Y. and M. Sakamoto (1970) : Primary production and metabolism of lakes, p. 208-225. In H. Yukawa (ed.), Profiles of Japanese Science and 
Scientists, Kodansha Ltd., Tokyo.

Suda, K., K. Seki J. Ishil, S. Takatani and S. Mizuuchi (1926): The report of limnological observation in Lake Biwa-ko (I). Bull. Kobe Marine Obs, 8: 1-103. (in Japanese).

(著者：遠藤修一, 滋賀大学教育学部地学教室, $\bar{\top} 520$ 大津市平津 2-5-1；奥村康昭, 大阪電気通信大学工学
部, 干 572 寝屋川市初町 18-8：Shuichi ENDOH, Departement of Earth Science, Shiga University 2-5-1 Hiratsu, Otsu, 520; Yasuaki Okumura, Faculty of Engineering, Osaka Electro-Communication University 18-8 Hatsu-Chou, Neyagawa, Osaka 572)

Received : 14 December 1992

Accepted : 12 March 1993 